\title{
REVIEW
}

\section{Biologic adjuvants for fracture healing}

\author{
Mandeep S Virk and Jay R Lieberman*
}

\section{Abstract}

Bone tissue has an exceptional quality to regenerate to native tissue in response to injury. However, the fracture repair process requires mechanical stability or a viable biological microenvironment or both to ensure successful healing to native tissue. An improved understanding of the molecular and cellular events that occur during bone repair and remodeling has led to the development of biologic agents that can augment the biological microenvironment and enhance bone repair. Orthobiologics, including stem cells, osteoinductive growth factors, osteoconductive matrices, and anabolic agents, are available clinically for accelerating fracture repair and treatment of compromised bone repair situations like delayed unions and nonunions. Preclinical and clinical studies using biologic agents like recombinant bone morphogenetic proteins have demonstrated an efficacy similar or better than that of autologous bone graft in acute fracture healing. A lack of standardized outcome measures for comparison of biologic agents in clinical fracture repair trials, frequent off-label use, and a limited understanding of the biological activity of these agents at the bone repair site have limited their efficacy in clinical applications.
\end{abstract}

\section{Introduction}

Fracture healing involves a well-orchestrated cascade of molecular and cellular events that recapitulate the process of embryonic endochondral bone formation and results in formation of new bone across the fracture site. The majority of fractures heal uneventfully, but it has been reported that $5 \%$ to $10 \%$ of all fractures either fail to unite or demonstrate a delay in healing [1]. Nonunions often require multiple surgical procedures to heal, leading to considerable morbidity, lost work days, and increased health-care costs [2]. Hence, there is a need to

*Correspondence: jrlieber@usc.edu

Department of Orthopaedic Surgery, Keck School of Medicine and University of Southern California, 1520 San Pablo Street, Suite 200, Los Angeles, CA 90033, USA develop therapeutic strategies that accelerate bone repair and that would either prevent or treat slow-healing fractures and nonunions.

Successful regeneration of bone involves the interplay of four critical elements: osteoinductive growth factors (induce differentiation of stem cells to osteoblasts), stem cells that respond to osteoinductive signals (osteogenic), an intact vascular supply, and, lastly, a scaffold that supports cellular attachment, proliferation, and ingrowth (osteoconductive matrix) [3,4]. An improved understanding of the molecular and cellular events that occur during bone repair and remodeling has led to the development of biologic therapies that enhance bone repair in fractures and nonunions. The US Food and Drug Administration (FDA) definition of biologics includes a wide range of products such as blood and blood components, somatic cells, gene therapy, tissues, and recombinant therapeutic proteins. The purpose of this article is to provide a comprehensive review of the biologic agents that can enhance bone repair and either are clinically available or are being assessed in clinical trials.

\section{Biologic adjuvants for enhancing bone repair}

Cell-based therapies, growth factors, osteoconductive matrices, and anabolic agents are available clinically to enhance bone repair. Osteoconductive matrices, including demineralized bone matrix and platelet-rich plasma, are not discussed in this review.

\section{Cell-based therapies}

Cellular therapies aim to replenish or augment (or both) the reparative cellular pool at the site of bone repair. Cellbased therapies involve transplantation of stem cells or progenitors (or both), which can be in the form of the processed native tissue, purified stem cells, cultureexpanded stems cells, or genetically modified stem cells [5]. Cell-based therapies are an attractive option for the treatment of compromised bone healing because they are usually autologous and therefore do not carry the risk of rejection.

\section{a. Stem cells}

Adult stem cells are pluripotent and are characterized by their distinct ability to self-renew [6]. They are present in 
all tissues, albeit in small numbers, and participate in physiologic remodeling/turnover of normal tissues and repair of the injured tissue. Adult stem cells are capable of differentiating into multiple types of progenitors, which are committed to become a particular phenotype (osteoblast, chondrocyte, fibroblast, adipocyte, tenocyte, and myoblast) in the presence of an appropriate biologic stimulus [7] (Figure 1).

Bone marrow is the most well-studied source of stem cells for bone repair. However, stem cells have been harvested from other tissues, including muscle, periosteum, adipose tissue, vascular pericytes, dermis, and peripheral blood [8]. Friedenstein and colleagues [9] were the first to demonstrate the presence, in the bone marrow, of fibroblast-like stem cells that were plastic adherent and capable of differentiating into multiple phenotypes. The fibroblast-like cells were later termed mesenchymal stem cells (MSCs) or bone marrow stromal cells.

Clinical studies have demonstrated the safety and efficacy of culture-expanded MSCs to enhance bone repair $[8,10-13]$. In a pilot clinical study, Marcacci and colleagues [11] used autologous bone marrow-derived culture-expanded osteoprogenitor cells seeded on a ceramic scaffold to treat four patients with diaphyseal bone defects (humerus, ulna, and tibia) that were stabilized with external fixators. All of the bone defects demonstrated complete healing at an average time of 6 months. There were no complications or adverse effects with this therapy during the follow-up period of 6 or 7 years. Quarto and colleagues [12] demonstrated successful healing of large bone defects (average of $5 \mathrm{~cm}$ ) in three patients (tibia, ulna, and humerus) with autologous bone marrow-derived MSCs. The culture-expanded MSCs were loaded on a ceramic scaffold and delivered at the time of surgery. In all three patients, radiographs and computed tomography scans demonstrated abundant callus formation and good integration at the interface with the host bone by the second month after surgery.

MSCs can also be differentiated in vitro to osteoblast precursors by growing them in an osteogenic differentiation media prior to transplantation in the host. In an open multicenter clinical trial, 64 patients with delayed healing of long bone fractures (femur, tibia, radius, ulna, and humerus) were randomly assigned to receive percutaneous injection of autologous cultured osteoblasts (Ossron; Sewon Cellontech, Seoul, Korea, $\mathrm{n}=31$ ) or no treatment (controls; $\mathrm{n}=33$ ) [13]. There was a significant increase in the radiographic callus formation score at 2 months in the cultured osteoblast treatment group compared with the controls. Although the percutaneous injections of culture-expanded osteoblasts led to increased bone formation in this study, no data regarding the final healing rates and the number of secondary interventions in the study groups were available.

Some proponents of this strategy believe that the MSCs participate in bone repair as a cellular source of growth factors and cytokines, which recruit osteoprogenitor cells from local and systemic sources via paracrine mechanisms. Whether the transplanted MSCs actually get incorporated in the regenerated bone is still a matter of debate $[5,6,14]$. Culture expansion of the stem cells has an advantage of increasing the number of cells that can be transplanted. However, it is associated with a theoretical risk of infection and can induce senescence and lead to loss of the multipotent potential of stem cells. Moreover, the culture expansion step may not be costeffective. Identifying anatomic sources with the highest concentration of adult stem cells and refinement of available techniques to purify and concentrate stem cells from the bone marrow would be a more cost-effective way of using this cell-based therapy.

\section{b. Bone marrow aspirate concentrate}

Bone marrow aspirate (BMA) contains stem cells that have the potential to transform into osteoblasts in response to osteoinductive signals. Bone marrow contains a heterogeneous population of cells, including stem cells, progenitor cells, and hematopoietic elements [8]. Traditionally, bone marrow aspiration has been performed from the iliac crest, but alternative sites, including the vertebral body, proximal humerus, proximal tibia, distal tibia, calcaneus, and fibula, have also been described. Bone marrow aspiration and percutaneous bone marrow grafting have been used to treat both delayed unions and nonunions [15-23] (Table 1).

Osteogenic properties of BMAs have been demonstrated in preclinical studies in small and large animal models of bone healing (fracture and critical-sized bone defect) and in clinical studies. Connolly and colleagues [18] were among the first to demonstrate the efficacy of percutaneous bone marrow injection for the treatment of tibia nonunions. In a cohort of 20 tibial nonunions, bone marrow was aspirated (average volume range of 100 to $150 \mathrm{~mL}$ ) from the posterior iliac crest under general anesthesia and delivered to the fracture site either via a percutaneous injection under radiographic guidance or as a paste mixed with demineralized bone matrix during an open procedure. Eighteen of the 20 tibia nonunions ( $90 \%$ success rate) healed at a median time of 6 months after the bone marrow injection. Transient discomfort at the donor site was the most common complication with bone marrow aspiration. Subsequently, in a larger study $(\mathrm{n}=100)$, Connolly [19] reported a success rate of approximately $80 \%$ with this therapy.

Khanal and colleagues [24], in a prospective randomized clinical trial, evaluated the role of percutaneous 


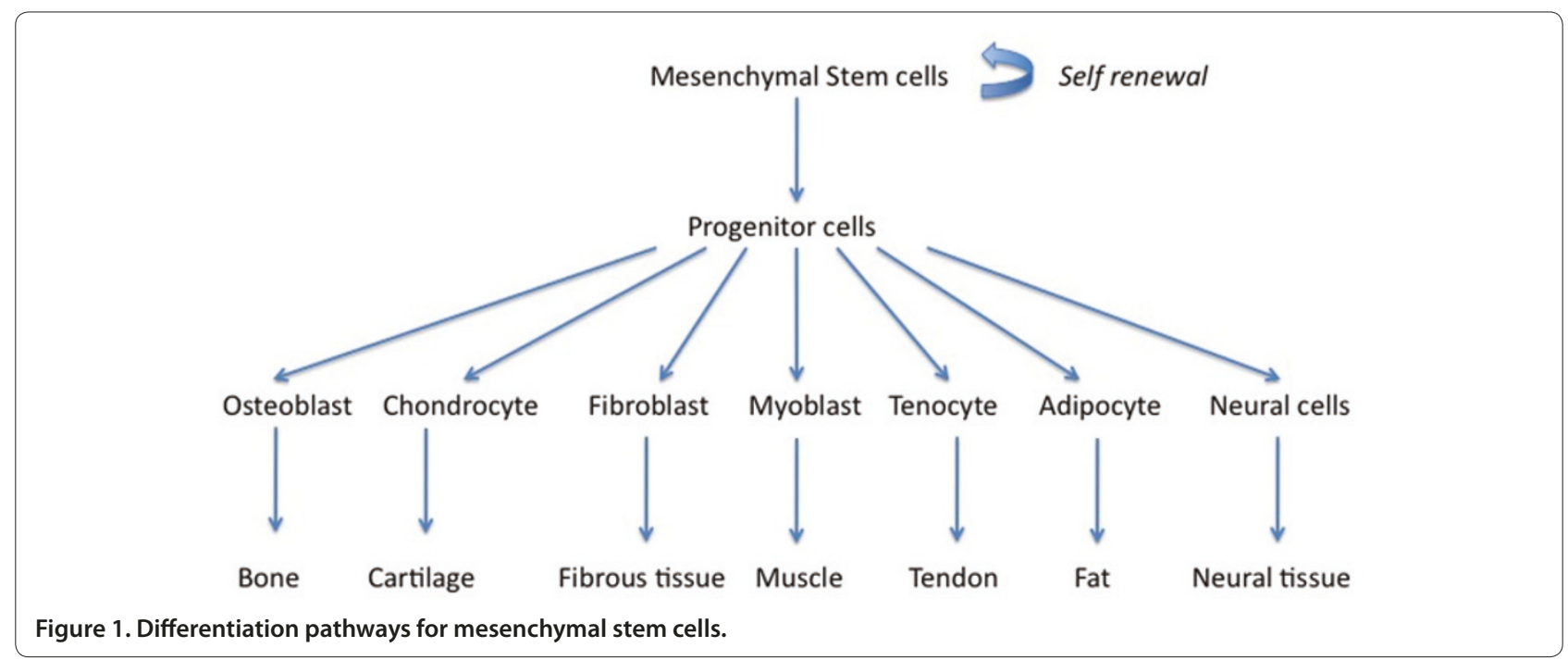

bone marrow grafting in acute tibia fractures. Forty patients with acute ( $<7$ days), closed tibia fractures were randomly assigned to receive either two injections of autologous BMAs and cast treatment $(n=20)$ or cast treatment alone $(\mathrm{n}=20)$. All bone marrow injections were administered percutaneously by using the palpation technique. There was a significant reduction in the time to osseous union in the percutaneous bone marrow grafting group (mean of 3.65 months; $P<0.0004$ ) compared with the controls (mean of 4.3 months). However, there was no significant difference $(P>0.05)$ between the two groups with respect to the final healing rates.

The optimum concentration and number of stem cells required to induce successful healing are not known. In a retrospective study involving 60 atrophic tibia nonunions (age range of 18 to 78 years), Hernigou and colleagues [25] demonstrated complete healing in 53 of 60 nonunions that were treated with a single injection of BMA. Bone marrow analysis of the aspirated specimens by using fibroblast colony-forming units (CFU-F) as a surrogate marker for osteogenic cells demonstrated that the tibial nonunions that failed to respond to the bone marrow injection $(n=7)$ received fewer than 30,000 progenitors but that the patients who achieved union received more than 30,000 progenitors [25]. The concentration of stem cells in the bone marrow is known to vary widely among the healthy adult population, and age, gender, site of aspiration, and volume of aspiration have been shown to affect the number of stem cells in the bone marrow [26-28]. Therefore, it is very difficult to predict the number of stem cells in the BMA on the basis of the volume of bone marrow concentrate alone. Moreover, with the currently available methods (CFU-F estimation in tissue culture), it is not possible to accurately determine the number of stem cells that are present in a given volume of BMA prior to percutaneous injection [29]. Because the biology of the fracture/nonunion and the healing response that occurs varies depending on the patient characteristics (smoking and diabetes), the personality of the fracture, and the microenvironment (previous radiation, fibrosis, infection), it may not be feasible to calculate a single absolute progenitor cell number that will induce successful healing in all types of nonunions in the entire skeleton. In fact, this therapy will have to be individualized for optimal efficacy.

Concentration of the BMA via centrifugation is one of the means of increasing the osteogenic efficacy of BMA $[19,25,26]$. In a preclinical study in our laboratory, we found that the stem cell concentration in healthy bone marrow donors (mean age of 25 years) ranged between 64 and 2,993 CFU-F/mL and that an average seven-fold increase in the $\mathrm{CFU} / \mathrm{mL}$ can be obtained following concentration of bone marrow by using a commercial centrifuge [26]. In clinical studies, an average four- to seven-fold increase in concentration of $\mathrm{CFU} / \mathrm{mL}$ has been reported with centrifugation $[16,25,30]$.

Percutaneous autologous bone marrow grafting is a safe and minimally invasive treatment that can be performed in an outpatient setting under local anesthesia. It avoids the complications associated with the open bone graft harvesting procedure. However, this technique, if used alone, may not be sufficient to induce healing of complex fractures with large bone gaps and a compromised biological environment at the fracture site. Furthermore, percutaneous injection of the bone marrow may not be feasible in nonunions with pre-existing angular deformities, as this would require an open procedure to access the deformity and nonunion $[16,19]$. 
Table 1. Clinical studies examining the efficacy of bone marrow injection for treatment of nonunions

\begin{tabular}{|c|c|c|}
\hline Study & Study design & Results \\
\hline \multirow{4}{*}{$\begin{array}{l}\text { Bhargava et al. [20] } \\
\text { (2007) }\end{array}$} & Prospective cohort & Radiographic union rate: $82 \%$ (23/28) \\
\hline & \multirow{3}{*}{$\begin{array}{l}\text { Twenty-eight patients were treated after an average of } 25 \text { weeks } \\
\text { after initial fracture (femur, ulna, tibia) with percutaneous BM } \\
\text { injection that was performed in the office under radiographic } \\
\text { control. }\end{array}$} & Average healing time: 12 weeks (range of 7 to 18 weeks) \\
\hline & & Five out of 28 patients required two BM injections. \\
\hline & & Average marrow volume injected: 50 to $90 \mathrm{~mL}$ \\
\hline \multirow{4}{*}{$\begin{array}{l}\text { Goel et al. [15] } \\
\text { (2005) }\end{array}$} & Prospective cohort & Radiographic union rate: $75 \%$ (15/20) \\
\hline & \multirow{3}{*}{$\begin{array}{l}\text { Twenty consecutive patients with established tibial nonunion } \\
\text { (>24 weeks after initial injury) were treated with casting and BM } \\
\text { injection under local anesthesia. }\end{array}$} & Average healing time: 14 weeks (range of 6 to 22 weeks) \\
\hline & & Average number of BM injections: 2.3 \\
\hline & & A maximum of $15 \mathrm{~mL}$ of marrow was injected in one sitting. \\
\hline \multirow{3}{*}{$\begin{array}{l}\text { Hernigou et al. [25] } \\
\text { (2005) }\end{array}$} & \multirow{3}{*}{$\begin{array}{l}\text { Sixty patients with tibial nonunions were treated with autologous } \\
\text { BM injections, which were performed under general anesthesia and } \\
\text { radiographic guidance. }\end{array}$} & Radiographic union rate: $~ 88 \%(53 / 60)$ \\
\hline & & Maximum concentrated marrow volume injected: $50 \mathrm{~mL}$ \\
\hline & & $\begin{array}{l}\text { All the nonunions that did not heal with BM injection had received } \\
\text { fewer than } 30,000 \text { progenitors. }\end{array}$ \\
\hline \multirow{4}{*}{$\begin{array}{l}\text { Wilkins et al. [29] } \\
\text { (2003) }\end{array}$} & \multirow{3}{*}{$\begin{array}{l}\text { Prospectively followed cohort of } 69 \text { long bone nonunions } \\
\text { (>6 months after initial injury) were treated with BM injection, } \\
\text { which was performed under regional or general anesthesia and } \\
\text { radiographic guidance. }\end{array}$} & Radiographic union rate: 88\% (61/69) \\
\hline & & Average healing time: 8.1 months (range of 2 months to 3 years) \\
\hline & & Eight nonunions required two injections. \\
\hline & Demineralized bone matrix was used as a carrier. & \\
\hline \multirow{3}{*}{$\begin{array}{l}\text { Garg et al. [22] } \\
\text { (1993) }\end{array}$} & Prospective cohort & Radiographic union rate: $85 \%$ (17/20) \\
\hline & \multirow{2}{*}{$\begin{array}{l}\text { Twenty consecutive patients with established long bone nonunion } \\
\text { were treated with casting and BM injection. }\end{array}$} & Average healing time: 5 months (range of 3 of 7 months) \\
\hline & & BM (15 to $20 \mathrm{~mL}$ ) was injected twice with an interval of 3 weeks. \\
\hline \multirow{3}{*}{$\begin{array}{l}\text { Sim et al. [21] } \\
\text { (1993) }\end{array}$} & Retrospective study & Radiographic union rate: $\sim 82 \%(9 / 11)$ \\
\hline & \multirow{2}{*}{$\begin{array}{l}\text { Eleven long bone nonunions were treated with autologous } \\
\text { BM injection, which was performed under regional or general } \\
\text { anesthesia under fluoroscopic guidance. }\end{array}$} & $\begin{array}{l}\text { Median radiographic healing time: } 17 \text { weeks (range of } 9 \text { to } \\
29 \text { weeks) }\end{array}$ \\
\hline & & Volume of marrow injected: 40 to $200 \mathrm{~mL}$ \\
\hline \multirow{4}{*}{$\begin{array}{l}\text { Connolly et al. [18] } \\
\text { (1991) }\end{array}$} & Case series & Radiographic union rate: 90\% (18/20) \\
\hline & \multirow{2}{*}{$\begin{array}{l}\text { Twenty tibial nonunions were treated with autologous BM injection, } \\
\text { which was performed under general anesthesia and radiographic } \\
\text { guidance. }\end{array}$} & Median healing time: 5 months \\
\hline & & Average marrow volume injected: 100 to $150 \mathrm{~mL}$ \\
\hline & $\begin{array}{l}\text { Casting }(n=10) \text { or intramedullary nail }(n=10) \text { was used for } \\
\text { immobilization. }\end{array}$ & Two out of 20 patients required two injections. \\
\hline
\end{tabular}

$\mathrm{BM}$, bone marrow.

\section{Growth factors \\ a. Bone morphogenetic proteins}

Bone morphogenetic proteins (BMPs) belong to the transforming growth factor-beta super family and are potent osteoinductive agents [31,32]. BMPs were discovered following a landmark experiment by Marshall Urist, who observed that demineralized, lyophilized segments of allogenic bone matrix implanted into the intramuscular pouches in rabbits led to reproducible induction of new bone [33]. Twenty members of the BMP family have been identified to date and are further subgrouped on the basis of their physiologic function and their gene sequences. BMPs are synthesized as large precursor molecules and are secreted as extracellular active dimeric forms. BMPs bind to the extracellular domain of the BMP receptors (serine/threonine kinase receptors; types I and II) and this in turn activates the smad-dependent and smad-independent signaling pathways that are responsible for modulating gene transcription $[34,35]$.

BMPs play a pivotal role in the growth and differentiation of various tissues and organs during embryonic development [34]. BMPs are involved in early limb development and embryonic patterning of limbs and induce differentiation of stem cells into cells of osteochondroblastic lineage. BMPs also enhance maturation and function of differentiated cells (osteoblast and chondrocyte) [31,32,35].

BMP-2 and BMP-7 (osteogenic protein-1) are the most well-studied BMPs and have been cloned and reproduced with recombinant technology. Multiple randomized clinical trials and small case series have evaluated the role 
Table 2. Summary of selected clinical trials of recombinant human bone morphogenetic protein-2 use in the treatment of acute fractures and nonunions

\begin{tabular}{|c|c|c|c|}
\hline $\begin{array}{l}\text { Investigator and } \\
\text { study design }\end{array}$ & Study groups & $\begin{array}{l}\text { Outcome measures } \\
\text { and follow-up (F/U) }\end{array}$ & Results \\
\hline $\begin{array}{l}\text { Aro et al. [38] (2011) } \\
\text { Randomized, prospective, } \\
\text { blinded study }\end{array}$ & $\begin{array}{l}\text { Two hundred seventy-seven patients } \\
\text { with open tibia fractures were randomly } \\
\text { assigned to receive standard of care } \\
\text { (SOC) (intramedullary nail and soft tissue } \\
\text { management; } n=138) \text { or SOC + rhBMP-2 } \\
(1.5 \mathrm{mg} / \mathrm{mL} ; \mathrm{n}=139) \text {. }\end{array}$ & $\begin{array}{l}\text { Clinical and radiographic } \\
\text { assessment of fracture healing, } \\
\text { rates of secondary intervention } \\
\text { F/U: } 1 \text { year }\end{array}$ & $\begin{array}{l}\text { rhBMP-2 did not significantly accelerate fracture } \\
\text { healing in open tibia fractures compared } \\
\text { with the controls. The study was halted prior } \\
\text { to completion because of a trend toward } \\
\text { increasing infection in the rhBMP-2 group. }\end{array}$ \\
\hline $\begin{array}{l}\text { Jones et al. [37] (2006) } \\
\text { Prospective, randomized, } \\
\text { multicenter, controlled, and } \\
\text { blinded study }\end{array}$ & $\begin{array}{l}\text { Thirty diaphyseal tibia fractures with cortical } \\
\text { defects were randomly assigned to two } \\
\text { treatment groups: rhBMP-2 + allograft } \\
(n=15) \text { or autogenous ICBG }(n=15) \text {. }\end{array}$ & $\begin{array}{l}\text { Clinical and radiographic } \\
\text { assessment of fracture healing, } \\
\text { functional outcome measure } \\
\text { (SMFA) } \\
\text { F/U: } 1 \text { year }\end{array}$ & $\begin{array}{l}\text { No significant differences in the healing rates, } \\
\text { number of secondary interventions, and } \\
\text { functional outcome scores between the two } \\
\text { groups }\end{array}$ \\
\hline $\begin{array}{l}\text { Swiontkowski et al. [85] } \\
\text { (2006) } \\
\text { Subgroup analysis of two } \\
\text { prospective randomized } \\
\text { studies }\end{array}$ & $\begin{array}{l}\text { Open tibia fractures were randomly assigned } \\
\text { to receive intramedullary nail and routine } \\
\text { soft tissue management alone }(n=169) \text { or in } \\
\text { combination with rhBMP- } 2(n=169) \text {. } \\
\text { Two subgroups: open fracture (grade IIIA and } \\
\text { IIIB; } n=131) \text { and the reamed nailing group } \\
(n=113)\end{array}$ & $\begin{array}{l}\text { Clinical and radiographic } \\
\text { assessment of fracture } \\
\text { healing, number of secondary } \\
\text { interventions and infection rates } \\
\text { F/U: } 1 \text { year }\end{array}$ & $\begin{array}{l}\text { rhBMP-2 decreased the frequency and } \\
\text { invasiveness of secondary interventions and } \\
\text { reduced the infection rates in grade III open } \\
\text { tibia fractures. }\end{array}$ \\
\hline $\begin{array}{l}\text { Govender et al. [36] (2002) } \\
\text { Prospective, randomized, } \\
\text { multicenter, controlled, } \\
\text { single-blind study }\end{array}$ & $\begin{array}{l}\text { Four hundred fifty patients with open tibia } \\
\text { fractures were randomly assigned to receive } \\
\text { SOC (intramedullary nail and soft tissue } \\
\text { management) or SOC + rhBMP-2 }(0.75 \mathrm{mg} / \\
\mathrm{mL} \text { ) or SOC + rhBMP-2 }(1.5 \mathrm{mg} / \mathrm{mL}) \text {. }\end{array}$ & $\begin{array}{l}\text { Clinical and radiographic } \\
\text { assessment of fracture healing, } \\
\text { rates of secondary intervention } \\
\text { F/U: } 1 \text { year }\end{array}$ & $\begin{array}{l}\text { rhBMP-2 }(1.5 \mathrm{mg} / \mathrm{mL}) \text { use reduced the } \\
\text { frequency and invasiveness of secondary } \\
\text { interventions, reduced infection rate (grades } \\
\text { IIIA and IIIB), and accelerated fracture and } \\
\text { wound healing. }\end{array}$ \\
\hline
\end{tabular}

ICBG, iliac crest bone graft; rhBMP-2, human recombinant bone morphogenetic protein-2; SMFA, short musculoskeletal function assessment.

of recombinant BMPs in the treatment of nonunions and acute fractures (Tables 2 and 3). The BESTT (BMP-2 Evaluation in Surgery for Tibial Trauma) trial was the first randomized controlled trial that evaluated the safety and efficacy of human recombinant BMP-2 (rhBMP-2) for treatment of open tibial fractures [36]. Acute open tibia fractures were randomly assigned to receive either standard of care (intramedullary nail fixation and routine soft tissue management; $\mathrm{n}=150$ ) or standard of care and rhBMP-2/absorbable collagen sponge (rhBMP-2/ACS) $(0.75 \mathrm{mg} / \mathrm{mL}, \mathrm{n}=151$ or $1.5 \mathrm{mg} / \mathrm{mL}, \mathrm{n}=149)$. The rhBMP-2 group (1.5 mg/mL) had significantly faster fracture healing, lower infection rates (Gustilo-Anderson type IIIA and IIIB fractures), and significant reduction in the frequency of secondary interventions as well as invasive interventions compared with the control group. There were no significant differences in the adverse events between the control and rhBMP-2 groups.

The efficacy of rhBMP-2 in combination with allograft was evaluated for the treatment of diaphyseal fractures with bone defects in a prospective randomized controlled trial (BESTT-ALL) [37]. Adult patients with a diaphyseal tibia fracture and a residual bone defect were randomly assigned to receive either an autogenous bone graft $(n=15)$ or a combination of an allograft and rhBMP-2 on a collagen sponge $(n=15)$. There were no significant differences with respect to healing rates between the autograft group (10 out of 15) and the rhBMP-2 (13 out of 15) group. Twelve milligrams of rhBMP-2, on average, was used in each defect. One third of the patients (5 out of 15) in the rhBMP-2 group developed persistent superficial erythema that resolved completely before 12 weeks, and one patient developed transient antibodies to type I bovine collagen.

In a recent clinical trial, a high rate of infection was noted in patients with open tibia fractures treated with rhBMP-2 [38]. Two hundred seventy-seven patients with open tibia fractures were randomly assigned to receive either standard of care (reamed intramedullary nail and soft tissue management) or standard of care and rhBMP-2/ACS (rhBMP-2 $1.5 \mathrm{mg} / \mathrm{mL}$ ). The primary endpoint was the proportion of subjects who demonstrate complete healing (clinical and radiographic) at 13 and 20 weeks after definitive wound closure. This study was halted prior to its completion because of a trend toward increased infection rates in the rhBMP-2 group (19\%) compared with the controls (11\%). The reason for the increased infection rate in the rhBMP-2 group in this study remains unclear.

Clinical trials with rhBMP-7 have also shown promise with respect to acute fractures and nonunions (Table 3 ). In the first prospective randomized trial, tibial nonunions that required internal fixation and supplemental bone grafting were randomly assigned to receive either 
Table 3. Summary of selected clinical trials of recombinant human bone morphogenetic protein-7 (OP-1) use in the treatment of acute fractures and nonunions

\begin{tabular}{|c|c|c|c|}
\hline $\begin{array}{l}\text { Investigator and } \\
\text { study design }\end{array}$ & Study groups & $\begin{array}{l}\text { Outcome measures } \\
\text { and follow-up }(F / U)\end{array}$ & Results \\
\hline Calori et al. [86] (2008) & \multirow{3}{*}{$\begin{array}{l}\text { One hundred twenty patients with long bone } \\
\text { nonunion were randomly assigned to receive } \\
\text { rhBMP-7 }(n=60) \text { or platelet-rich plasma } \\
(n=60) \text {. }\end{array}$} & \multirow{2}{*}{$\begin{array}{l}\text { Clinical and radiographic union } \\
\text { at } 9 \text { months }\end{array}$} & \multirow{3}{*}{$\begin{array}{l}\text { Higher union rates }(86.7 \%) \text {, shorter healing } \\
\text { time, and decreased number of secondary } \\
\text { interventions with rhBMP-7 treatment }\end{array}$} \\
\hline \multirow{2}{*}{$\begin{array}{l}\text { Prospective randomized } \\
\text { study }\end{array}$} & & & \\
\hline & & Minimum F/U: 9 months & \\
\hline Ekrol et al. [40] (2008) & \multirow{3}{*}{$\begin{array}{l}\text { Thirty patients with distal radius malunion } \\
\text { undergoing corrective osteotomy (stabilized } \\
\text { with external fixator or pi plate) were randomly } \\
\text { assigned to receive rhBMP-7 }(n=14) \text { or } \\
\text { autologous ICBG }(n=16) \text {. }\end{array}$} & Clinical, radiographic, and & \multirow{3}{*}{$\begin{array}{l}\text { Time to healing was faster in patients who } \\
\text { received autologous ICBG when compared } \\
\text { with rhBMP-7 (in conjunction with a pi plate). }\end{array}$} \\
\hline \multirow{2}{*}{$\begin{array}{l}\text { Prospective randomized } \\
\text { study }\end{array}$} & & functional outcome measures & \\
\hline & & Minimal F/U: 1 year & \\
\hline Ristiniemi et al. [87] (2007) & \multirow{3}{*}{$\begin{array}{l}\text { Twenty distal tibia fractures treated with } \\
\text { external fixator and rhBMP- } 7 \text { were compared } \\
\text { with } 20 \text { matched controls that were treated } \\
\text { with external fixator alone. }\end{array}$} & Time to healing, rate of & \multirow{3}{*}{$\begin{array}{l}\text { Early radiographic healing, higher union rates, } \\
\text { reduced time for which the external fixator was } \\
\text { required, and significant reduction in the time } \\
\text { away from work in the rhBMP-7 group }\end{array}$} \\
\hline \multirow[t]{2}{*}{$\begin{array}{l}\text { Prospective study with } \\
\text { matched controls }\end{array}$} & & $\begin{array}{l}\text { secondary interventions, } \\
\text { duration of external fixator, and } \\
\text { time away from work }\end{array}$ & \\
\hline & & F/U: 1 year & \\
\hline Bilic et al. [88] (2006) & \multirow{3}{*}{$\begin{array}{l}\text { Seventeen patients with proximal pole } \\
\text { scaphoid fractures were randomly assigned to } \\
\text { receive autologous ICBG }(n=6) \text {, autologous } \\
\text { ICBG+rhBMP-7 }(n=6) \text {, or allograft+rhBMP-7 } \\
(n=5) \text {. }\end{array}$} & Clinical and radiographic & \multirow{3}{*}{$\begin{array}{l}\text { Enhanced bone healing and reduced healing } \\
\text { time in the rhBMP- } 7 \text { treatment groups } \\
\text { compared with the autologous ICBG group }\end{array}$} \\
\hline \multirow[t]{2}{*}{$\begin{array}{l}\text { Prospective randomized } \\
\text { study }\end{array}$} & & $\begin{array}{l}\text { (x-rays, computed tomography } \\
\text { scans, bone scan) outcomes } \\
\text { measures }\end{array}$ & \\
\hline & & F/U: 2 years & \\
\hline McKee et al. [89] (2002) & \multirow{2}{*}{$\begin{array}{l}\text { One hundred twenty-four open tibial } \\
\text { shaft fractures treated with irrigation and } \\
\text { debridement and intramedullary nailing were } \\
\text { randomly assigned to receive OP- }(n=62) \\
\text { or no treatment }(n=62) \text { at the time of final } \\
\text { wound closure. }\end{array}$} & Radiographic and clinical & \multirow{2}{*}{$\begin{array}{l}\text { Significant reduction in the number of } \\
\text { secondary interventions with OP-1 treatment }\end{array}$} \\
\hline $\begin{array}{l}\text { Prospective randomized } \\
\text { trial with preliminary } \\
\text { results only }\end{array}$ & & $\begin{array}{l}\text { Time to healing and rate } \\
\text { of secondary interventions } \\
\text { Minimum F/U: } 6 \text { months }\end{array}$ & \\
\hline $\begin{array}{l}\text { Friedlaender et al. [39] } \\
\text { (2001) }\end{array}$ & \multirow{2}{*}{$\begin{array}{l}\text { One hundred twenty-four tibial nonunions } \\
\text { treated with intramedullary rod insertion were } \\
\text { randomly assigned to receive either rhBMP-7 } \\
\text { or autograft. }\end{array}$} & $\begin{array}{l}\text { Clinical and radiographic } \\
\text { measures }\end{array}$ & \multirow{2}{*}{$\begin{array}{l}\text { No significant differences in the clinical and } \\
\text { radiographic results between the rhBMP-7 and } \\
\text { the autologous bone graft groups }\end{array}$} \\
\hline $\begin{array}{l}\text { Prospective, randomized, } \\
\text { partially blinded } \\
\text { multicenter trial }\end{array}$ & & F/U: 9 months & \\
\hline Geesink et al. [90] (1999) & \multirow{3}{*}{$\begin{array}{l}\text { Twenty-four patients with fibular osteotomy } \\
\text { were prospectively randomly assigned to } \\
\text { receive rhBMP-7 + collagen matrix }(n=6) \text {, } \\
\text { collagen carrier }(n=6) \text {, demineralized bone } \\
(n=6) \text {, or no treatment }(n=6) \text {. }\end{array}$} & Clinical, radiographic, and dual- & \multirow{3}{*}{$\begin{array}{l}\text { Improved healing rates of fibular defects (5/6) } \\
\text { with the rhBMP-7 treatment }\end{array}$} \\
\hline \multirow[t]{2}{*}{$\begin{array}{l}\text { Prospective, randomized, } \\
\text { and double-blinded trial }\end{array}$} & & $\begin{array}{l}\text { energy x-ray absorptiometry } \\
\text { scan }\end{array}$ & \\
\hline & & F/U: 1 year & \\
\hline
\end{tabular}

ICBG, iliac crest bone graft; rhBMP-7, human recombinant bone morphogenetic protein-7.

rhBMP-7 $(\mathrm{n}=63)$ or fresh autograft bone $(\mathrm{n}=61)$ [39]. The primary end-point of this study was rate of fracture union as determined by the clinical criteria at 9 months after surgery. rhBMP-7 ( $81 \%$ healing rate) demonstrated clinical equivalence with respect to fracture union compared with the autograft group ( $85 \%$ healing rate) at 9 months $(P=0.0524)$ and 2 years $(P=0.93)$. Interestingly, the proportion of patients who were smokers and had atrophic nonunion was higher $(P=0.57$ and $P=0.48$, respectively) in the rhBMP-7 treatment group compared with the autograft group.

The safety and osteogenic efficacy of rhBMP-7 were subsequently demonstrated in other prospective studies that evaluated healing of critical-sized fibular defects, scaphoid nonunions, and long bone nonunions with this recombinant protein (Table 3). However, in a prospective study, Ekrol and colleagues [40] reported conflicting results with the use of rhBMP-7 in operative management of distal radius malunions. Thirty patients with a distal radius malunion were stabilized with an external fixator or a pi plate and were randomly assigned to receive either rhBMP-7 $(n=14)$ or autogenous bone graft $(n=16)$. The autogenous bone graft group had higher healing rates and shorter time to union $(P=0.02)$. However, the study sample size was small and there was no power analysis presented in the study for sample size calculation. The rhBMP-7 treatment group had higher rates of inflammatory swelling and osteolysis at the site of malunion site.

rhBMPs are among the most common biologic agents used for enhancing bone repair. However, there are 
certain hurdles limiting their efficacious use in humans. First, rhBMPs have a short half-life and a single dose may not be enough for healing of large bone defects that are seen with revision arthroplasty and high-energy trauma $[4,41]$. Second, despite recent advances in the delivery systems for BMPs, the ideal carrier matrix for rhBMPs has not been identified. Currently, an ACS is commonly used as a delivery vehicle for rhBMPs, but kinetic studies demonstrate that half of the drug is eluted in the first hour and two thirds of the drug is released in the first four days [42]. Third, supraphysiologic doses (in milligrams) of rhBMPs are currently being used in humans, and the long-term effects of this dose on non-musculoskeletal tissue or growing skeleton are not clearly known. Consequently, rhBMPs are not FDA-approved in the pediatric age group, in pregnant patients, or in the presence of tumors. Finally, there are complications associated with rhBMPs that either are related to the initial inflammatory response induced by the proteins (neck swelling, seroma, neuritis) or are an extension of their osteoinductive function (heterotopic ossification, paraplegia, transient osteopenia) [43]. The complications in cervical spine can be life-threatening (severe respiratory compromise) and cause serious morbidity (heterotopic formation, severe dysphagia, and increased risk of infection). rhBMP-2 is not FDA-approved for use in the cervical spine, and the FDA issued a health-care alert regarding rhBMP-2 use in the cervical spine in 2008 [43-45].

Currently, with respect to fractures and nonunions, rhBMP-2 is FDA-approved for the treatment of acute open tibial shaft fractures stabilized with an intramedullary nail and treated within 14 days of the initial injury. rhBMP-7 has received humanitarian device exemption approval as an alternative to the autograft in recalcitrant long bone nonunions in which the use of autograft is not feasible and the alternative treatments have failed.

Recombinant BMPs are very expensive, but proponents of this therapy believe that it may be more cost-effective given that it may minimize secondary procedures. According to a recent Cochrane review, there was limited evidence to suggest that BMP may be more effective than controls for acute tibial fracture healing [46]. However, rhBMP use in acute open tibial fractures might be more favorable economically when used in patients with the most severe open fractures (grade III open fractures) [46]. Therefore, although BMPs are the most potent osteoinductive agents available today, their cost and high doses needed to induce an appropriate biologic response in humans limit their utility.

\section{b. Fibroblast growth factor}

The fibroblast growth factor (FGF) family consists of polypeptide growth factors (FGF1-10 and FGF16-23) that are implicated in regulation of cell proliferation, differentiation, and apoptosis. FGFs mediate their cellular responses by binding to their receptors (FGFRs 1-4), and this results in activation of intracellular signaling pathways that regulate gene expression [47]. Cell biology and genetic studies in humans and mice have shown that the FGFs are important regulators of osteoblast and chondroblast differentiation. In the osteoblasts, FGF-FGFR signaling promotes expression of multiple genes that are involved in all stages of osteogenesis. FGF signaling also controls osteoblast gene expression and apoptosis [48].

Preclinical studies in both small and large animal fracture models (rat, dog, and monkey) have shown that FGF-2 enhances bone repair and induces early healing [49]. Two prospective clinical trials have examined the safety and efficacy of rhFGF-2 in fracture and osteotomy healing [50,51]. Both studies suggest a beneficial effect of rhFGF-2 on bone repair. However, none of the clinical studies has demonstrated any significant improvement in the healing rates or reduction in the number of secondary interventions compared with the controls. Clearly, additional clinical studies are required to show equivalence or a significant advantage of this therapy over the current gold standard, autologous bone graft.

\section{c. Platelet-derived growth factor}

Members of the platelet-derived growth factor (PDGF) family are dimers of disulphide-linked polypeptide chain (PDGF A-D) and play a significant role in embryonic development and organogenesis, including the axial and craniofacial skeleton [52]. PDGFs exist mainly as homodimers (PDGF-AA, -BB, -CC, and -DD), and their cellular responses are mediated via two tyrosine kinase receptors (PDGFR- $\alpha$ and PDGFR- $\beta$ ) [53]. In adult life, platelets are a rich source of PDGF, especially the PDGF$\mathrm{BB}$ isoform. PDGFs are mitogenic and chemotactic for cells of mesenchymal origin and can induce their differentiation into multiple cell types, including fibroblasts and osteoblasts. PDGFs also upregulate the angiogenic response at the site of tissue repair by increasing the expression of vascular endothelial growth factor [52].

Preclinical fracture studies suggest that rhPDFG-BB enhances bone repair and improves biomechanical characteristics of the callus in a compromised biological environment (diabetic or osteoporosis) [54]. The safety and efficacy of rhPDGF have been evaluated in prospective randomized clinical trials in foot and ankle arthrodesis $[55,56]$. In a prospective controlled pilot trial under the FDA-approved Investigational Device Exemption, 20 adult patients who required ankle or hindfoot fusion were randomly assigned to receive rhPDGF $(n=14)$ or autogenous bone graft $(n=6)$. The primary end-point was time to osseous union. There were no significant differences with respect to radiographic 
osseous union between the rhPDGF group (85\%) and the autogenous graft group (100\%) at 3 years. However, the study was underpowered. RhPDGF-BB in combination with beta tricalcium phosphate is currently approved by the FDA for the treatment of periodontal bone defects. Further clinical studies are necessary to evaluate the role of PDGF in the management of acute fractures and nonunions.

\section{Anabolic therapies Parathyroid hormone}

Parathyroid hormone (PTH) is a polypeptide protein hormone ( 84 amino acids) that plays an important role in calcium homeostasis and bone remodeling. The biologic functions of PTH are mediated by binding to and activation of G protein-coupled PTH receptor, which in turn activates the protein kinase $\mathrm{A}$ and protein kinase $\mathrm{C}$ signaling pathways [57]. In addition, PTH activates the $\beta$ arrestin-mediated extracellular-regulated kinase signaling pathway. The principal physiologic function of endogenous PTH is to increase the blood calcium levels by increasing the osteoclast-mediated bone resorption (catabolic effect). However, intermittent administration of exogenous PTH leads to increased bone formation and improves the microarchitectural strength of the bone. The molecular and cellular mechanisms underlying this anabolic effect are not clearly understood. However, in vitro studies and in vivo data in mice have demonstrated that intermittent PTH administration promotes prosurvival and pro-differentiating signaling in the osteoblasts and leads to an increase in osteoblast numbers and therefore more bone formation [57].

Teriparatide is a synthetic/recombinant human PTH consisting of a 1-34 N-terminal amino acid sequence of the intact PTH molecule $[58,59]$. In preclinical animal models (fracture, osteotomy, and distraction osteogenesis), intermittent administration of teriparatide, such as with once-daily injection (dose range of 5 to $200 \mu \mathrm{g} / \mathrm{kg}$ ), has been shown to enhance early chondrogenesis and endochondral ossification, which results in increased callus formation (callus volume and bone mineral content) and superior biomechanical strength of the callus [60]. Clinical trials have reported mixed results with recombinant PTH peptides in fracture healing [6163]. In a prospective randomized multicenter clinical trial, postmenopausal women with distal radius fractures that were treated with closed reduction were randomly assigned to receive once-daily injections of placebo ( $\mathrm{n}=34)$ or $20 \mu \mathrm{g}$ of teriparatide $(\mathrm{n}=34)$ or $40 \mu \mathrm{g}$ of teriparatide $(\mathrm{n}=34)$ for 8 weeks [63]. There was no significant difference between the placebo and $40 \mu \mathrm{g}$ teriparatide group with respect to time to restoration of cortical continuity, which was the primary end-point of this study. However, post hoc analysis found that the lower dose $(20 \mu \mathrm{g})$ of PTH in the study significantly reduced $(P=0.006)$ the time to cortical restoration. The authors of the study subsequently performed a separate post hoc subgroup analysis to identify the differences in the qualitative appearance of callus at earlier time points [61]. There was a trend toward improvement of early callus formation with the teriparatide treatment.

Recombinant PTH (1-84) is approved for treatment of osteoporosis in Europe and recently was evaluated for its role in the healing of pelvic fractures in older patients [62]. Sixty-five patients who had osteoporosis (T score of less than -2.5), were more than 70 years old, and sustained a unilateral pelvic fracture were randomly assigned to receive daily injections of $100 \mu \mathrm{g}$ of PTH 1-84 (every third patient was enrolled; $\mathrm{n}=21$ ) or no treatment (control; $\mathrm{n}=44$ ). All patients received oral calcium and vitamin D3 during the entire study period. The primary outcome of this study was time to radiographic and clinical fracture healing. At 8 weeks, which was the primary end-point of the study, all of the fractures in the PTH group and four fractures in the control group had healed $(P<0.001)$. There was a significant reduction in the median time to complete radiographic healing in the PTH group (7.8 weeks; $P<0.001)$ compared with the placebo (12.6 weeks). Furthermore, the functional outcome scores were significantly better $(P<0.001)$ in the PTH group. This study demonstrates that PTH 1-84 accelerates pelvic fracture healing and improves functional outcome in older female patients with osteoporosis. A weakness of this study was that the patients were recruited chronologically and the sample sizes were unbalanced (every third patient was allocated to the PTH treatment group). Interestingly, all of the patients in the experimental group were recruited from one center. Despite these study design limitations, the study represents a major step toward identifying the indications and feasibility of systemic anabolic therapy for enhancing fracture healing.

PTH is generally considered safe in humans and has been well tolerated without significant adverse effects in clinical trials. However, rat toxicity studies have demonstrated a dose- and duration-dependent appearance of osteosarcomas with high doses of teriparatide [59]. Even though the doses of teriparatide used in the animal studies were far higher and their durations were longer compared with the doses used in humans, teriparatide is contraindicated in patients with primary bone tumors, including osteosarcoma, and in patients with metastatic bone tumors. Other contraindications include renal failure, Paget's disease of bone, metabolic bone disease other than osteoporosis, any condition that leads to hypercalcemia, and pediatric patients [59]. Teriparatide is not FDA-approved in the US for use in acute fractures or nonunions, and its current approval is restricted to 
postmenopausal women and men with osteoporosis who are at high risk for sustaining fragility fractures. However, a number of case studies in the literature demonstrate the successful use of PTH to treat fractures [62,64-66].

\section{Fracture repair in the future}

An ideal bone graft should be osteoinductive, osteoconductive, osteogenic, and angiogenic. Furthermore, it should provide mechanical support and promote physiologic healing without any significant adverse effects. Regenerative strategies like the use of recombinant growth factors or osteogenic cells or osteoconductive scaffolds alone or in combination may be effective for delayed unions or simple nonunions [4]. However, large bone defects with compromised biology may not be amenable to simple regenerative strategies and will require polytherapy, which incorporates all of the critical components that are required for bone healing.

Ex vivo regional gene therapy using genetically manipulated mesenchymal stem cells is one of the ideal strategies for managing difficult bone repair scenarios $[3,4]$. The major advantage of ex vivo gene therapy is that the genetically manipulated stem cells not only secrete osteoinductive growth factors that recruit host osteoprogenitor cells via paracrine signaling (osteoinduction) but also differentiate into osteoblasts via an autocrine mechanism and participate in new bone formation (osteogenic) $[3,67,68]$. Consequently, more robust new bone formation is seen in the critical-sized bone defect model with ex vivo gene therapy than seen with the use of rhBMP-2 [41]. Unfortunately, gene therapy has safety issues that need to be addressed before it can be made clinically available for treatment of nonunions. Another major limitation of ex vivo gene therapy is the need for culture expansion of stem cells prior to implantation, which is time-consuming and not cost-effective. We have developed a novel 'same day' ex vivo gene therapy strategy in our laboratory, where fresh bone marrow cells are genetically manipulated with a lentiviral vector expressing BMP-2, seeded onto an osteoconductive scaffold, and implanted into the host bone defect in a single sitting without the need to expand these cells in culture [69] (Figure 2). Results from a preclinical study in a rat critical-sized femoral defect model demonstrated that the quality of new bone formed with the 'same day' strategy was superior to that formed with the conventional ex vivo gene therapy. The 'same day' strategy represents a significant advance in the field of ex vivo regional gene therapy because it offers a solution to the limitations associated with the culture expansion process required in the traditional ex vivo approach. This strategy could be cost-effective when adapted for human use.

There is also interest in the in vivo approach, in which the gene of interest is injected directly into the bone defect site [70,71]. The advantage of this strategy is that it is simple. The disadvantage is that there must be sufficient cells to respond to these signals. There has been increasing interest in using off-the-shelf biologic products for healing critical-sized defects [72]. Freezedried cortical allografts coated with cell-free viral vectors (AAV) expressing BMPs have shown significant promise in the healing of critical-sized bone defects in preclinical studies. The healing rates are comparable to those of autograft, but there is reduced graft resorption and improved torsional biomechanical strength in healed defects. However, safety issues related to viral vectors are critical impediments to its clinical use [72].

There is a great deal of interest in the development of biologic agents that can be administered systemically to enhance bone repair [73]. The major advantage of this strategy is that healing can be stimulated for a prolonged period of time and it is not invasive. Recombinant PTH is available clinically, but two more agents, sclerostin antibody and anti-Dkk-1 (anti-Dickopff antibody), are currently being developed for enhancing bone repair in humans. Sclerostin is a member of the DAN family of glycoprotein that acts as a negative regulator of osteoblast development and bone formation [74]. Although the specific molecular mechanism by which sclerostin inhibits bone formation is an area of continuing investigation, basic science and translational studies have demonstrated that sclerostin can bind to BMPs and Wnt co-receptors (LRP 5 and 6) and inhibit BMP-mediated bone formation as well as the canonical Wnt signaling pathway [75]. In preclinical fracture studies, systemic administration of neutralizing antibodies to sclerostin significantly increases the bone mass and callus and biomechanical strength of the callus [76]. Using a rat closed femur fracture model and a primate fibular osteotomy model, Ominsky and colleagues [76] demonstrated that the systemic administration of sclerostin antibody significantly increased the callus bone mass and bone volume fraction at the site of fracture/osteotomy and improved the biomechanical strength of the callus. Unpublished data from our laboratory demonstrate that sclerostin antibody enhances bone repair in a rat criticalsized femoral defect model. Femoral defects that were treated with sclerostin antibody demonstrated increased new bone formation at the defect site, and a few of these defects actually healed completely [77]. Sclerostin antibody does not appear to be an osteoinductive agent but clearly can promote bone repair when used in an appropriate clinical scenario. Sclerostin antibody is currently being assessed in clinical trials.

Dickkopf-1 (Dkk-1) is a secreted glycoprotein and is a potent antagonist of the $\mathrm{Wnt} / \beta$-catenin pathway, which is one of the important regulators of bone mass [78]. Systemic administration of anti-Dkk-1 antibody in 


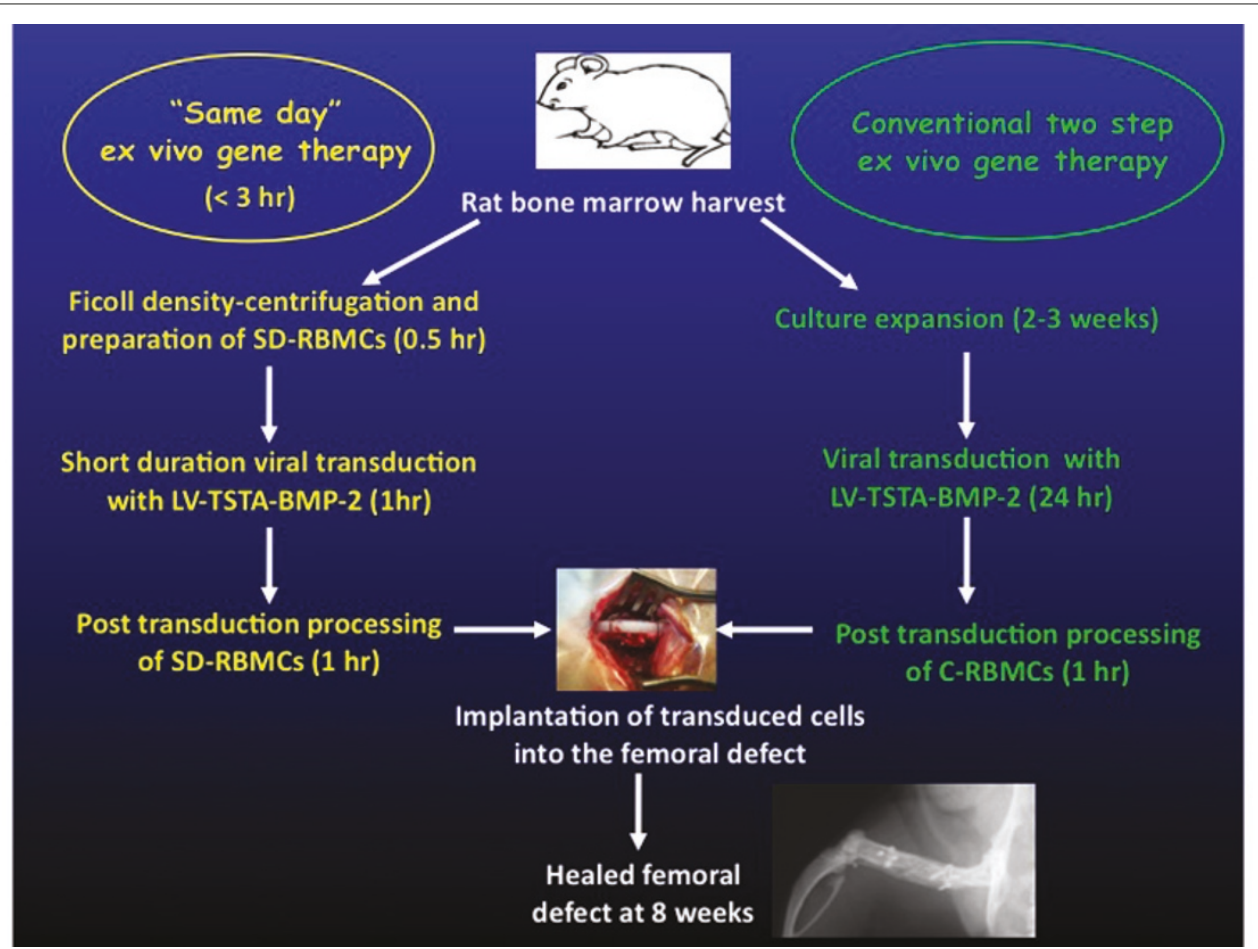

Figure 2. 'Same day' ex vivo gene therapy. BMP-2, bone morphogenetic protein-2; C, cultured; LV, lentiviral vector; RBMC, rat bone marrow cell; SD, same day; TSTA, two-step transcriptional amplification.

preclinical animal models has demonstrated enhanced endochondral bone formation and improved fixation strength of the implants in bone by increasing trabecular bone formation around the implant [79].

The potential advantage of these systemic agents is that they can be used as an adjuvant to promote fracture healing. For example, it is often difficult to determine when to intervene in a tibia fracture that is healing slowly. These agents have the potential to promote healing without surgical intervention. These agents could also be used to enhance bone repair after bone grafting procedures. This hypothesis will have to be proven in clinical trials. However, if effective in this scenario, this strategy would represent a paradigm shift in the management of difficult fractures. The administration of a systemic agent could continue to promote bone repair for months after the index surgical procedure.

Not all of the biologic therapies are the same with respect to their osteoinductive, osteogenic, or osteoconductive potential. The size of the bone defect, the extent of soft tissue injury, and the biological potential of the host all influence the type of treatment that is necessary to promote bone repair. The osteoinductive effect of BMP-2 and -7 is well documented and supported by level 1 evidence in clinical trials. However, other biologic agents either are lacking level 1 evidence or did not show efficacy in level 1 studies. It is essential that the clinical studies evaluating these biologic agents include the following: well-defined inclusion and exclusion criteria, the use of objective measures to assess bone healing, and validated patient-reported outcome measures to determine efficacy [80-82]. Reynolds and colleagues [83] developed a union ratio, which computes the union between host callus and graft, as a novel biometric for non-invasive assessment of functional strength and failure risk of allogeneic bone graft. This tool may be of value to investigators trying to determine defect healing. Finally, cost-effectiveness must also be demonstrated for all of these treatment regimens [84].

\section{Conclusions}

Successful fracture healing requires mechanical stability and a viable biologic microenvironment. Fractures with a compromised biology will benefit from treatment options that can augment the biologic potential at the site of bone repair. Recombinant growth factors (rhBMPs), cell-based therapies (BMAs and stem cells), and anabolic agents $(\mathrm{rhPTH})$ all have clinical potential. Both preclinical and early clinical data with the use of these agents are promising and suggest a potential pivotal role in the treatment of acute fractures, delayed unions, and nonunions. Studies are required to optimize these therapies, define their specific indications for use, and address safety issues. 
This article is part of the series on Cutting edge research and advances in orthopaedic research, edited by Edward Schwarz and Jay Lieberman. Other articles in this series can be found at http://arthritis-research.com/series/othopaedics

\section{Abbreviations}

ACS, absorbable collagen sponge; BMA, bone marrow aspirate; BMP, bone morphogenetic protein; CFU, colony-forming units; CFU-F, fibroblast colonyforming units; Dkk-1, Dickkopf-1; FDA, US Food and Drug Administration; FGF, fibroblast growth factor; FGFR, fibroblast growth factor receptor; MSC, mesenchymal stem cell; PDGF, platelet-derived growth factor; PTH, parathyroid hormone; rhBMP, human recombinant bone morphogenetic protein.

\section{Competing interests}

JRL has received research support from Amgen, Inc. MSV has no competing interests.

\section{Published: 30 November 2012}

\section{References}

1. Axelrad TW, Kakar S, Einhorn TA: New technologies for the enhancement of skeletal repair. Injury 2007, 38 Suppl 1:S49-62.

2. Heckman JD, Sarasohn-Kahn J: The economics of treating tibia fractures. The cost of delayed unions. Bull Hosp Jt Dis 1997, 56:63-72.

3. Lieberman JR: Orthopaedic gene therapy. Fracture healing and other nongenetic problems of bone. Clin Orthop Relat Res 2000, (379 Suppl):S156-158.

4. Carofino BC, Lieberman JR: Gene therapy applications for fracture-healing. J Bone Joint Surg Am 2008, 90 Suppl 1:99-110.

5. Patterson TE, Kumagai K, Griffith L, Muschler GF: Cellular strategies for enhancement of fracture repair. J Bone Joint Surg Am 2008, 90 Suppl 1:111-119.

6. Muschler GF, Midura RJ: Connective tissue progenitors: practical concepts for clinical applications. Clin Orthop Relat Res 2002, (395):66-80.

7. Khosla S, Westendorf JJ, Modder UI: Concise review: Insights from normal bone remodeling and stem cell-based therapies for bone repair. Stem Cells 2010, 28:2124-2128.

8. Giordano A, Galderisi U, Marino IR: From the laboratory bench to the patient's bedside: an update on clinical trials with mesenchymal stem cells. J Cell Physio/ 2007, 211:27-35.

9. Friedenstein AJ, Petrakova KV, Kurolesova Al, Frolova GP: Heterotopic of bone marrow. Analysis of precursor cells for osteogenic and hematopoietic tissues. Transplantation 1968, 6:230-247.

10. Bajada S, Harrison PE, Ashton BA, Cassar-Pullicino VN, Ashammakhi N, Richardson JB: Successful treatment of refractory tibial nonunion using calcium sulphate and bone marrow stromal cell implantation. J Bone Joint Surg Br 2007, 89:1382-1386.

11. Marcacci M, Kon E, Moukhachev V, Lavroukov A, Kutepov S, Quarto R, Mastrogiacomo M, Cancedda R: Stem cells associated with macroporous bioceramics for long bone repair: 6- to 7-year outcome of a pilot clinical study. Tissue Eng 2007, 13:947-955.

12. Quarto R, Mastrogiacomo M, Cancedda R, Kutepov SM, Mukhachev V, Lavroukov A, Kon E, Marcacci M: Repair of large bone defects with the use of autologous bone marrow stromal cells. NEngl J Med 2001, 344:385-386.

13. Kim SJ, Shin YW, Yang KH, Kim SB, Yoo MJ, Han SK, Im SA, Won YD, Sung YB, Jeon TS, Chang CH, Jang JD, Lee SB, Kim HC, Lee SY: A multi-center, randomized, clinical study to compare the effect and safety of autologous cultured osteoblast (Ossron) injection to treat fractures. BMC Musculoskelet Disord 2009, 10:20.

14. Tseng SS, Lee MA, Reddi AH: Nonunions and the potential of stem cells in fracture-healing. J Bone Joint Surg Am 2008, 90 Suppl 1:92-98.

15. Goel A, Sangwan SS, Siwach RC, Ali AM: Percutaneous bone marrow grafting for the treatment of tibial non-union. Injury 2005, 36:203-206.

16. Hernigou P, Mathieu G, Poignard A, Manicom O, Beaujean F, Rouard H: Percutaneous autologous bone-marrow grafting for nonunions. Surgical technique. J Bone Joint Surg Am 2006, 88 Suppl 1 Pt 2:322-327.

17. Galois L, Bensoussan D, Diligent J, Pinzano A, Henrionnet C, Choufani E, Stoltz $J F$, Mainard D: Autologous bone marrow graft and treatment of delayed and non-unions of long bones: technical aspects. Biomed Mater Eng 2009,
19:277-281

18. Connolly JF, Guse R, Tiedeman J, Dehne R: Autologous marrow injection as a substitute for operative grafting of tibial nonunions. Clin Orthop Relat Res 1991, (266):259-270.

19. Connolly JF: Clinical use of marrow osteoprogenitor cells to stimulate osteogenesis. Clin Orthop Relat Res 1998, (355 Suppl):S257-266.

20. Bhargava R, Sankhla S, Gupta A, Changani R, Gagal K: Percutaneous autologus bone marrow injection in the treatment of delayed or nonunion. Indian J Orthop 2007, 41:67-71.

21. Sim R, Liang TS, Tay BK: Autologous marrow injection in the treatment of delayed and non-union in long bones. Singapore Med J 1993, 34:412-417.

22. Garg NK, Gaur S, Sharma S: Percutaneous autogenous bone marrow grafting in 20 cases of ununited fracture. Acta Orthop Scand 1993, 64:671-672.

23. Kettunen J, Makela EA, Turunen V, Suomalainen O, Partanen K: Percutaneous bone grafting in the treatment of the delayed union and non-union of tibial fractures. Injury 2002, 33:239-245.

24. Khanal GP, Garg M, Singh GK: A prospective randomized trial of percutaneous marrow injection in a series of closed fresh tibial fractures. Int Orthop 2004, 28:167-170.

25. Hernigou P, Poignard A, Beaujean F, Rouard H: Percutaneous autologous bone-marrow grafting for nonunions. Influence of the number and concentration of progenitor cells. J Bone Joint Surg Am 2005, 87:1430-1437.

26. Cuomo AV, Virk M, Petrigliano F, Morgan EF, Lieberman JR: Mesenchymal stem cell concentration and bone repair: potential pitfalls from bench to bedside. J Bone Joint Surg Am 2009, 91:1073-1083.

27. Muschler GF, Boehm C, Easley K: Aspiration to obtain osteoblast progenitor cells from human bone marrow: the influence of aspiration volume. J Bone Joint Surg Am 1997, 79:1699-1709.

28. Seebach C, Henrich D, Tewksbury R, Wilhelm K, Marzi I: Number and proliferative capacity of human mesenchymal stem cells are modulated positively in multiple trauma patients and negatively in atrophic nonunions. Calcif Tissue Int 2007, 80:294-300.

29. Wilkins RM, Chimenti BT, Rifkin RM: Percutaneous treatment of long bone nonunions: the use of autologous bone marrow and allograft bone matrix. Orthopedics 2003, 26 (5 Suppl):s549-554.

30. Sakai S, Mishima H, Ishii T, Akaogi H, Yoshioka T, Uemura T, Ochiai N: Concentration of bone marrow aspirate for osteogenic repair using simple centrifugal methods. Acta Orthop 2008, 79:445-448

31. Chen D, Zhao M, Mundy GR: Bone morphogenetic proteins. Growth Factors 2004, 22:233-241.

32. Lieberman JR, Daluiski A, Einhorn TA: The role of growth factors in the repair of bone. Biology and clinical applications. J Bone Joint Surg Am 2002, 84-A:1032-1044

33. Urist MR: Bone: formation by autoinduction. Science 1965, 150:893-899

34. Bragdon B, Moseychuk O, Saldanha S, King D, Julian J, Nohe A: Bone morphogenetic proteins: a critical review. Cell Signal 2011, 23:609-620.

35. Canalis E, Economides AN, Gazzerro E: Bone morphogenetic proteins, their antagonists, and the skeleton. Endocr Rev 2003, 24:218-235.

36. Govender S, Csimma C, Genant HK, Valentin-Opran A, Amit Y, Arbel R, Aro H, Atar D, Bishay M, Börner MG, Chiron P, Choong P, Cinats J, Courtenay B, Feibel R, Geulette B, Gravel C, Haas N, Raschke M, Hammacher E, van der Velde D, Hardy P, Holt M, Josten C, Ketterl RL, Lindeque B, Lob G, Mathevon H, McCoy $G$, Marsh D, et al:: Recombinant human bone morphogenetic protein-2 for treatment of open tibial fractures: a prospective, controlled, randomized study of four hundred and fifty patients. J Bone Joint Surg Am 2002, 84-A:2123-2134

37. Jones AL, Bucholz RW, Bosse MJ, Mirza SK, Lyon TR, Webb LX, Pollak AN, Golden JD, Valentin-Opran A: Recombinant human BMP-2 and allograft compared with autogenous bone graft for reconstruction of diaphyseal tibial fractures with cortical defects. A randomized, controlled trial. J Bone Joint Surg Am 2006, 88:1431-1441.

38. Aro HT, Govender S, Patel AD, Hernigou P, Perera de Gregorio A, Popescu GI, Golden JD, Christensen J, Valentin A: Recombinant human bone morphogenetic protein-2: a randomized trial in open tibial fractures treated with reamed nail fixation. J Bone Joint Surg Am 2011, 93:801-808.

39. Friedlaender GE, Perry CR, Cole JD, Cook SD, Cierny G, Muschler GF, Zych GA, Calhoun JH, LaForte AJ, Yin S: Osteogenic protein-1 (bone morphogenetic protein-7) in the treatment of tibial nonunions. J Bone Joint Surg Am 2001, 83-A Suppl 1 (Pt 2):S151-158

40. Ekrol I, Hajducka C, Court-Brown C, McQueen MM: A comparison of 
RhBMP-7 (OP-1) and autogenous graft for metaphyseal defects after osteotomy of the distal radius. Injury 2008, 39 Suppl 2:S73-82.

41. Lieberman JR, Daluiski A, Stevenson S, Wu L, McAllister P, Lee YP, Kabo JM, Finerman GA, Berk AJ, Witte ON: The effect of regional gene therapy with bone morphogenetic protein-2-producing bone-marrow cells on the repair of segmental femoral defects in rats. J Bone Joint Surg Am 1999, 81:905-917.

42. Seeherman HJ, Li XJ, Bouxsein ML, Wozney JM: rhBMP-2 induces transient bone resorption followed by bone formation in a nonhuman primate core-defect model. J Bone Joint Surg Am 2010, 92:411-426.

43. Carragee EJ, Hurwitz EL, Weiner BK: A critical review of recombinant human bone morphogenetic protein-2 trials in spinal surgery: emerging safety concerns and lessons learned. Spine J 2011, 11:471-491

44. Shields LB, Raque GH, Glassman SD, Campbell M, VitazT, Harpring J, Shields CB: Adverse effects associated with high-dose recombinant human bone morphogenetic protein-2 use in anterior cervical spine fusion. Spine (Phila Pa 1976) 2006, 31:542-547.

45. Vaidya R, Carp J, Sethi A, Bartol S, Craig J, Les CM: Complications of anterior cervical discectomy and fusion using recombinant human bone morphogenetic protein-2. Eur Spine J 2007, 16:1257-1265.

46. Garrison KR, Shemilt I, Donell S, Ryder JJ, Mugford M, Harvey I, Song F, Alt V: Bone morphogenetic protein (BMP) for fracture healing in adults. Cochrane Database Syst Rev (6):CD006950.

47. Beenken A, Mohammadi M: The FGF family: biology, pathophysiology and therapy. Nat Rev Drug Discov 2009, 8:235-253.

48. Marie PJ: Fibroblast growth factor signaling controlling osteoblast differentiation. Gene 2003, 316:23-32.

49. Kawaguchi $\mathrm{H}$ : [Bone fracture and the healing mechanisms. Fibroblast growth factor-2 and fracture healing]. Clin Calcium 2009, 19:653-659. In Japanese.

50. Kawaguchi H, Oka H, Jingushi S, Izumi T, Fukunaga M, Sato K, Matsushita T, Nakamura K: A local application of recombinant human fibroblast growth factor 2 for tibial shaft fractures: a randomized, placebo-controlled trial. J Bone Miner Res 2010, 25:2735-2743.

51. Kawaguchi H, Jingushi S, Izumi T, Fukunaga M, Matsushita T, Nakamura T, Mizuno K, Nakamura T, Nakamura K: Local application of recombinant human fibroblast growth factor-2 on bone repair: a dose-escalation prospective trial on patients with osteotomy. J Orthop Res 2007, 25:480-487.

52. Hollinger JO, Hart CE, Hirsch SN, Lynch S, Friedlaender GE: Recombinant human platelet-derived growth factor: biology and clinical applications. $J$ Bone Joint Surg Am 2008, 90 Suppl 1:48-54.

53. Andrae J, Gallini R, Betsholtz C: Role of platelet-derived growth factors in physiology and medicine. Genes Dev 2008, 22:1276-1312.

54. DiGiovanni CW, Petricek JM: The evolution of rhPDGF-BB in musculoskeletal repair and its role in foot and ankle fusion surgery. Foot Ankle Clin 2010, 15:621-640.

55. Daniels T, DiGiovanni C, Lau JT, Wing K, Younger A: Prospective clinical pilot trial in a single cohort group of rhPDGF in foot arthrodeses. Foot Ankle Int 2010, 31:473-479.

56. Digiovanni CW, Baumhauer J, Lin SS, Berberian WS, Flemister AS, Enna MJ, Evangelista P, Newman J: Prospective, randomized, multi-center feasibility trial of rhPDGF-BB versus autologous bone graft in a foot and ankle fusion model. Foot Ankle Int 2011, 32:344-354

57. Jilka RL: Molecular and cellular mechanisms of the anabolic effect of intermittent PTH. Bone 2007, 40:1434-1446.

58. Bukata SV, Puzas JE: Orthopedic uses of teriparatide. Curr Osteoporos Rep 2010, 8:28-33.

59. Rubin MR, Bilezikian JP: Parathyroid hormone as an anabolic skeletal therapy. Drugs 2005, 65:2481-2498.

60. Ellegaard M, Jørgensen NR, Schwarz P: Parathyroid hormone and bone healing. Calcif Tissue Int 2010, 87:1-13.

61. Aspenberg P, Johansson T: Teriparatide improves early callus formation in distal radial fractures. Acta Orthop 2010, 81:234-236.

62. Peichl $P$, Holzer LA, Maier R, Holzer G: Parathyroid hormone 1-84 accelerates fracture-healing in pubic bones of elderly osteoporotic women. J Bone Joint Surg Am 2011, 93:1583-1587.

63. Aspenberg P, Genant HK, Johansson T, Nino AJ, See K, Krohn K, GarcíaHernández PA, Recknor CP, Einhorn TA, Dalsky GP, Mitlak BH, Fierlinger A, Lakshmanan MC: Teriparatide for acceleration of fracture repair in humans: a prospective, randomized, double-blind study of 102 postmenopausal women with distal radial fractures. J Bone Miner Res 2010, 25:404-414.
64. Chintamaneni S, Finzel K, Gruber BL: Successful treatment of sternal fracture nonunion with teriparatide. Osteoporos Int 2010, 21:1059-1063.

65. Rubery PT, Bukata SV: Teriparatide may accelerate healing in delayed unions of type III odontoid fractures: a report of 3 cases. J Spinal Disord Tech 2010, 23:151-155.

66. Oteo-Alvaro A, Moreno E: Atrophic humeral shaft nonunion treated with teriparatide (rh PTH 1-34): a case report. J Shoulder Elbow Surg 2010, 19:e22-28

67. Gazit D, Turgeman G, Kelley P, Wang E, Jalenak M, Zilberman Y, Moutsatsos I: Engineered pluripotent mesenchymal cells integrate and differentiate in regenerating bone: a novel cell-mediated gene therapy. J Gene Med 1999, 1:121-133

68. Gamradt SC, Abe N, Bahamonde ME, Lee YP, Nelson SD, Lyons KM, Lieberman $J R$ : Tracking expression of virally mediated BMP- 2 in gene therapy for bone repair. Clin Orthop Relat Res 2006, 450:238-245.

69. Virk MS, Sugiyama O, Park SH, Gambhir SS, Adams DJ, Drissi H, Lieberman JR: 'Same day' ex-vivo regional gene therapy: a novel strategy to enhance bone repair. Mol Ther 2011, 19:960-968.

70. Evans CH, Ghivizzani SC, Robbins PD: The 2003 Nicolas Andry Award Orthopaedic gene therapy. Clin Orthop Relat Res 2004, (429):316-329.

71. Betz OB, Betz VM, Nazarian A, Pilapil CG, Vrahas MS, Bouxsein ML, Gerstenfeld $\mathrm{LC}$, Einhorn TA, Evans $\mathrm{CH}$ : Direct percutaneous gene delivery to enhance healing of segmental bone defects. J Bone Joint Surg Am 2006, 88:355-365.

72. Yazici C, Takahata M, Reynolds DG, Xie C, Samulski RJ, Samulski J, Beecham EJ, Gertzman AA, Spilker M, Zhang X, O'Keefe RJ, Awad HA, Schwarz EM: Self-complementary AAV2.5-BMP2-coated femoral allografts mediated superior bone healing versus live autografts in mice with equivalent biomechanics to unfractured femur. Mol Ther 2011, 19:1416-1425.

73. Bukata SV: Systemic administration of pharmacological agents and bone repair: what can we expect. Injury 2011, 42:605-608

74. van Bezooijen RL, ten Dijke P, Papapoulos SE, Lowik CW: SOST/sclerostin, an osteocyte-derived negative regulator of bone formation. Cytokine Growth Factor Rev 2005, 16:319-327.

75. ten Dijke P, Krause C, de Gorter DJ, Lowik CW, van Bezooijen RL: Osteocytederived sclerostin inhibits bone formation: its role in bone morphogenetic protein and Wnt signaling. J Bone Joint Surg Am 2008, 90 Suppl 1:31-35.

76. Ominsky MS, Li C, Li X, Tan HL, Lee E, Barrero M, Asuncion FJ, Dwyer D, Han CY, Vlasseros F, Samadfam R, Jolette J, Smith SY, Stolina M, Lacey DL, Simonet WS, Paszty C, Li G, Ke HZ: Inhibition of sclerostin by monoclonal antibody enhances bone healing and improves bone density and strength of nonfractured bones. J Bone Miner Res 2011, 26:1012-1021.

77. Virk MS, Saquib SF, Farhang A, Lieberman JR: Influence of sclerostin antibody on bone repair in a rat femoral defect model. In 55 th Annual Orthopaedic Research Society Meeting. Las Vegas, NV; 2009.

78. Daoussis D, Andonopoulos AP: The emerging role of dickkopf-1 in bone biology: is it the main switch controlling bone and joint remodeling? Semin Arthritis Rheum 2011 41:170-177.

79. Agholme F, Isaksson H, Kuhstoss S, Aspenberg P: The effects of Dickkopf-1 antibody on metaphyseal bone and implant fixation under different loading conditions. Bone 2011, 48:988-996.

80. Vannabouathong C, Spraque S, Bhandari M: Guidelines for fracture healing assessments in clinical trials. Part I: definitions and endpoint committees. Injury 2011, 42:314-316.

81. Morshed S, Bhandari M: Clinical trial design in fracture-healing research: meeting the challenge. J Bone Joint Surg Am 2008, 90 Suppl 1:55-61.

82. Morshed S, Corrales L, Genant H, Miclau T 3rd: Outcome assessment in clinical trials of fracture-healing. J Bone Joint Surg Am 2008, 90 Suppl 1:62-67.

83. Reynolds DG, Shaikh S, Papuga MO, Lerner AL, O'Keefe RJ, Schwarz EM, Awad HA: muCT-based measurement of cortical bone graft-to-host union. J Bone Miner Res 2009, 24:899-907.

84. Garrison KR, Donell S, Ryder J, Shemilt I, Mugford M, Harvey I, Song F: Clinical effectiveness and cost-effectiveness of bone morphogenetic proteins in the non-healing of fractures and spinal fusion: a systematic review. Health Technol Assess 2007, 11:1-150, iii-iv.

85. Swiontkowski MF, Aro HT, Donell S, Esterhai JL, Goulet J, Jones A, Kregor PJ, Nordsletten L, Paiement G, Patel A: Recombinant human bone morphogenetic protein- 2 in open tibial fractures. A subgroup analysis of data combined from two prospective randomized studies. J Bone Joint Surg Am 2006, 88:1258-1265.

86. Calori GM, Tagliabue L, Gala L, d'Imporzano M, Peretti G, Albisetti W: 
Application of rhBMP-7 and platelet-rich plasma in the treatment of long bone non-unions: a prospective randomised clinical study on 120 patients. Injury 2008, 39:1391-1402.

87. Ristiniemi J, Flinkkila T, Hyvonen P, Lakovaara M, Pakarinen H, Jalovaara P: RhBMP-7 accelerates the healing in distal tibial fractures treated by external fixation. J Bone Joint Surg Br 2007, 89:265-272.

88. Bilic R, Simic P, Jelic M, Stern-Padovan R, Dodig D, van Meerdervoort HP, Martinovic S, Ivankovic D, Pecina M, Vukicevic S: Osteogenic protein-1 (BMP-7) accelerates healing of scaphoid non-union with proximal pole sclerosis. Int Orthop 2006, 30:128-134.

89. McKee MD, Schemitsch EH, Waddell JP, Kreder HJ, Stephen DJG, Leighton RK, Buckley RE, Powell JN, Wild LM, Blachut PA, O'Brien PJ, Pirani S, McCormack TG; and the Canadian Orthopaedic Trauma Society St Michael's Hospital, University of Toronto, Toronto, Ontario, Canada (a-Stryker Biotech, Inc.): The effect of human recombinant bone morphogenic protein (RHBMP-7) on the healing of open tibial shaft fractures: results of a multi-center, prospective, randomized clinical trial. In Proceedings of the 18th Annual Meeting of the Orthopaedic Trauma Association. 11-13 Oct. 2002; Toronto, ON, Canada; 2002:157-158.

90. Geesink RG, Hoefnagels NH, Bulstra SK: Osteogenic activity of OP-1 bone morphogenetic protein (BMP-7) in a human fibular defect. J Bone Joint Surg Br 1999, 81:710-718.

doi:10.1186/ar4053

Cite this article as: Virk MS, Lieberman JR: Biologic adjuvants for fracture healing. Arthritis Research \& Therapy 2012, 14:225. 